\title{
DIAGNOSIS DETECTION OF ACUTE RESPIRATOR INFECTION WITH FORWARD CHAINING METHOD
}

\author{
Tri Wisnu Pamungkas'; Resi Taufan²; Petrus Damianus³; Gabriel Vangeran Saragih"; ${ }^{4}$ Tri Retnasari5 \\ 1,2,3,4Program Studi Ilmu Komputer \\ 5Program Studi Teknik Informatika \\ Universitas Nusa Mandiri \\ https://www.nusamandiri.ac.id/ \\ 14002332@nusamandiri.ac.id ${ }^{1}$, resitauf1508@nusamandiri.ac.id ${ }^{2}$, 14002337@nusamandiri.ac.id ${ }^{3}$, \\ 14002327@nusamandiri.ac.id ${ }^{4}$, tri.trs@nusamandiri.ac.id ${ }^{5}$
}

(*) Corresponding Author

\begin{abstract}
Many acute respiratory infections or ARI are caused by viruses that attack the nose, trachea (breathing tube), or the lungs. It can be said that ARI is caused by inflammation that disrupts a person's breathing process. If not treated quickly, ARI can spread to all respiratory systems and prevent the body from getting proper oxygen, moreover it can cause the loss of a person's life. This research aims to diagnose ARI as an early step in practicing artificial intelligence in medicine, designing and apply an expert system that can diagnose ARI. The procedure used in this study uses forward chaining with tracking that begins with input data, and then creates a diagnosis or solution. The expert system used to diagnose acute respiratory inflammation uses the Forward chaining procedure with a data-driven approach, in this approach tracking starts from input data, and then seeks to draw conclusions, so that it can be used, diagnose the type of disease associated with the ARI disease experienced by showing the existing signs.
\end{abstract}

Keywords: forward chaining, ispa, expert system

Abstrak-Infeksi saluran pernapasan akut ataupun ISPA banyak diakibatkan oleh virus yang menyerang hidung, trakea (pipa pernapasan), ataupun paruparu. Dan dapat dikatakan ISPA disebabkan peradangan yang mengacaukan proses pernafasan seseorang. Apabila tidak lekas ditangani, ISPA dapat menyebar ke segala sistem pernapasan serta membuat badan tidak mendapatkan oksigen yang layak, apalagi yang lebih parah dapat menimbulkan hilangnya nyawa seseorang. Riset ini bertujuan untuk mendiagnosa penyakit ISPA selaku langkah dini mempraktikkan kecerdasan buatan dalam dunia kedokteran, merancang serta mengaplikasikan sistem ahli yang dapat mendiagnosa penyakit ISPA. Tata cara yang digunakan dalam penelitian ini menggunakan forward chaining dengan pelacakan yang diawali dari data masukan, serta berikutnya menciptakan diagnosa ataupun pemecahan. Sistem pakar yang digunakan untk mendiagnosa peradangan saluran pernafasan akut memakai tata cara Forward chaining (pelacakan ke depan) dengan pendekatan yang di jalani dengan informasi (data-driven), dalam pendekatan ini pelacakan diawali dari data masukan, serta berikutnya berupaya menggambarkan kesimpulan, sehingga bisa mendiagnosa tipe penyakit yang berhubungan dengan penyakit ISPA yang dialami dengan memperlihatkan tanda-tanda yang ada.

Kata Kunci: forward chaining, ispa, sistem pakar

\section{INTRODUCTION}

ARI is a disease that is easily spread. People who are easily affected by this disease are those who have immune system disorders, elderly people, and children are also susceptible to this disease, because their immune systems are not fully developed. Acute respiratory infections according to (Mardiah et al., 2017) is a major health problem. Some ARI diseases include influenza, sinusitis, laryngitis, pharyngitis, tonsillitis, epiglottitis and pneumonia. (Wulandari \& Basuki, 2019).

The problem that often arises according to (Nuraeni et al., 2016) is the availability of expert doctors or experts who have knowledge in certain fields which is quite limited while many patients need to be diagnosed with their illness and treated immediately. A system is needed according to (Ramadhana et al., 2020) that can provide convenience for the public to know and be aware of the early detection of ARI disease. So that people can know the first action that must be taken before going to the doctor for further treatment.

There are several studies that have been carried out in diagnosing diseases, including a webbased pregnancy diagnosis expert system (Abdillah et al., 2018), an expert system for diagnosing breast 
cancer and how to treat it (Puspitawati, 2018), expert applications for diagnosing skin diseases using this method, forward chaining (Nuraeni et al., 2016), the design of an expert system for diagnosing renal tubular acidosis using the certainty factor method (Fanny et al., 2017), an expert system for diagnosing allergic diseases in children based on the forward chaining method in the city of Batam (Jarti \& Trisno, 2017), an expert system for diagnosing diseases caused by smoking using the forward chaining method (Hidayat \& Gumilang, 2017), an expert system for diagnosing osteoporosis in the elderly using the forward chaining method (Permata Sari \& Realize, 2019).

Of these methods, the most frequently used is the forward chaining method, forward chaining is a strategy to predict or find a solution to a problem that starts with a set of known facts (Permata Sari \& Realize, 2019). In the Forward Chaining method, tracking starts from tracing all data and rules to achieve the goal (Nuraeni et al., 2016), with the Forward Chaining method departing from left to right, namely from the premise to the final conclusion, this method is often called data driven, namely The search is controlled by the data provided (Kusuma et al., 2018), so that the forward chaining method will be used to match the symptoms in the form of questions which will be answered by the user with existing rules, then conclusions will be obtained (Afandi \& Sulistyo, 2019).

With the existence of a system that is useful for diagnosing disease, an expert system is a good solution to identify and provide data about diseases designed by the system so that humans can immediately recognize data about prevention and methods of curing the disease. The expert system used to diagnose throat diseases with the forward chaining method can be used to determine various diseases of the respiratory tract.

The purpose of this study is to facilitate the public in obtaining the necessary data about throat and respiratory diseases clearly and completely, especially those related to the symptoms of ARI.

\section{MATERIALS AND METHODS}

Expert System is a system or program that acts like an expert (Masya et al., 2016), and according to (Minarni et al., 2017) an expert system is a computer-based application that is used to solve problems as thought by experts. The experts in question are people who have special skills who can solve problems that cannot be solved by ordinary people (Hidayat \& Gumilang, 2017). Most rulebased expert systems use an inference strategy called the ponen mode. Based on this strategy, if there is an "IF A THEN B" rule, and if it is known that
A is true, then it can be concluded that B is also true. There are two approaches to control inference in a rule-based expert system, namely backward chaining and forward chaining (Wahyudi et al., 2016). The forward chaining method is said to be an inference method that makes reasoning from a problem to its solution (Permata Sari \& Realize, 2019). While the inference engine is a computer program that provides a methodology for reasoning about the information contained in the rule or knowledge base, this component has a mindset and reasoning used by experts in solving a problem (Maliki \& Dangkua, 2018). In this study, using the forward chaining method modeling for the manufacture of an expert system for diagnosing acute respiratory infections. The forward chaining method is a decision-making method commonly used in expert systems (Kusuma et al., 2018).

The types of systems that can use forward chaining tracking techniques are: (Kusuma et al., 2018).

a. A system represented by one or more conditions.

b. For each condition, the system searches the knowledge base for rules that correspond to the conditions in the if section.

c. Each rule can generate a new condition from the conclusion requested in the then section, this new condition can be added to other conditions that already exist.

d. Every condition added to the system will be processed, if a condition is found, the system will return to step 2 and look for the rules in the knowledge base again, if there is no new conclusion, the session ends.

Before implementing an expert system, first design the algorithm of the expert system. Algorithms are used to help make it easier to read the program created. In Figure 1 describes the process to get the results of a diagnosis of a disease, starting from the diagnosis form then answering questions in the form of answer choices that are in accordance with the symptoms after that display the results of the diagnosis. 


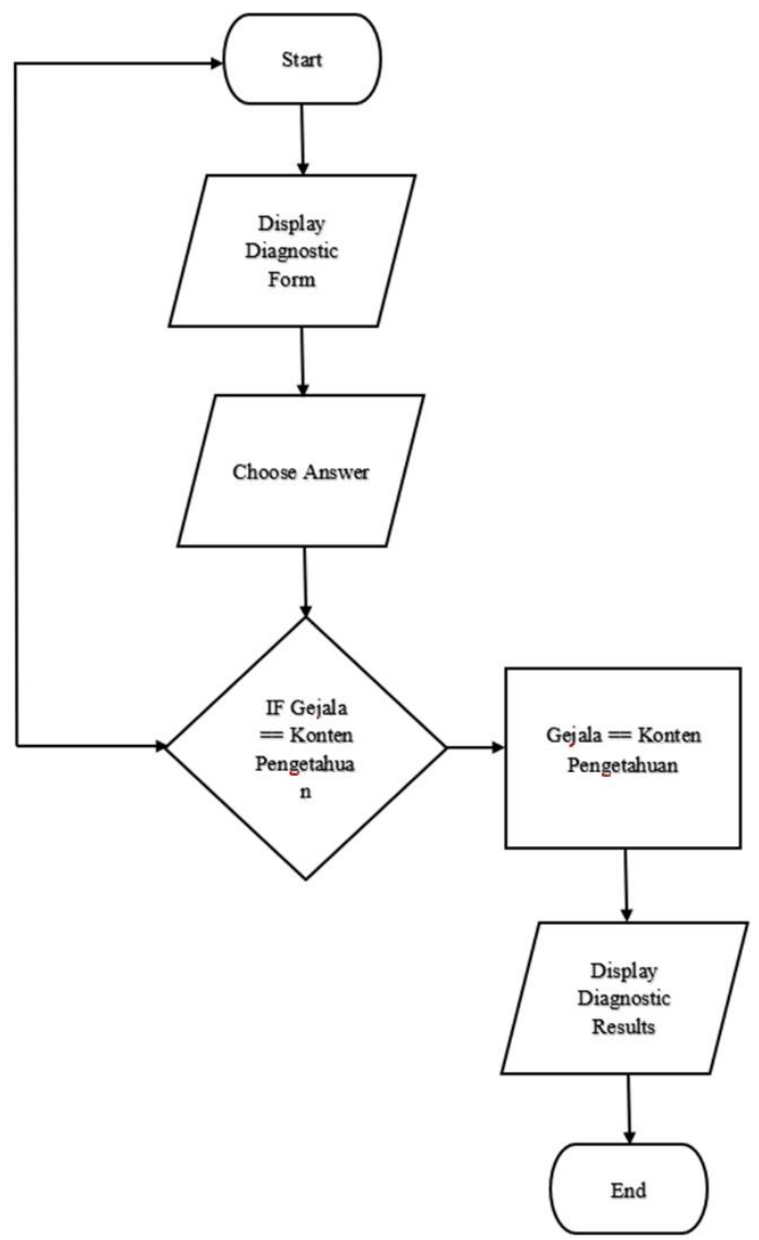

Figure 1. Algorithm Design

\section{RESULTS AND DISCUSSION}

An expert system in the form of representation of knowledge from experts, where the content of this knowledge is composed of facts and rules. This knowledge content is composed of expert tables, expert rules and expert decision trees. The following is a detailed explanation of the knowledge content created:

\section{Expert Table.}

This design consists of symptom data and disease data which is a very important object to assist in processing an expert system for diagnosing acute respiratory infections. The following table of experts is designed to simplify the process of processing data entered into knowledge content. In table 1 there is a disease code and disease data that is the sample in this study which serves as initial data. The disease code is an alias of the disease data which is used as a comparison in the 'IF' condition.

\begin{tabular}{lll}
\hline No & Kode Penyakit & Nama Penyakit \\
\hline 1 & P01 & Rhinosinusitis / Sinusistis \\
\hline 2 & P02 & $\begin{array}{l}\text { Tonsilitis, Faringitis, } \\
\text { Laringitis (Radang } \\
\text { Tenggorokan) }\end{array}$ \\
\hline 3 & P03 & Epiglotis \\
\hline 4 & P04 & Bronkitis \\
\hline 5 & P05 & Bronkiolitis \\
\hline 6 & P06 & Pneumonia \\
\hline 7 & P07 & Pleuritis \\
\hline 8 & P08 & Commond Cold \\
\hline 9 & P09 & ILI (Influenza Like Illness) \\
\hline
\end{tabular}

While in table 2 contains data gejala which contains kode gejala and the name of the symptom by adjusting the types of diseases that can be used in diagnosing ARI disease experienced by the user. The symptom code is an alias of the symptom name which is used as a comparison in the 'IF' condition.

Table 2. Data Gejala

\begin{tabular}{ccl}
\hline No & Kode Gejala & \multicolumn{1}{c}{ Nama Gejala } \\
\hline 1 & G01 & Demam \\
\hline 2 & G02 & Batuk-Batuk \\
\hline 3 & G03 & Hidung Tersumbat / Pilek \\
\hline 4 & G04 & Sakit Kepala / Pusing \\
\hline 5 & G05 & $\begin{array}{l}\text { Sakit Tenggorokan / Susah } \\
\text { Menelan }\end{array}$ \\
\hline 6 & G06 & Lesu / Lemas \\
\hline 7 & G07 & Sesak Napas \\
\hline 8 & G08 & Frekuensi Napas Cepat \\
\hline 9 & G09 & Suara Napas Kasar \\
\hline 10 & G10 & $\begin{array}{l}\text { Nafsu Makan Berkurang / Susah } \\
\text { Makan }\end{array}$ \\
\hline 11 & G11 & $\begin{array}{l}\text { Berkurang Nya Indra Pengecap } \\
\text { Dan Bau }\end{array}$ \\
\hline 12 & G12 & Suara Serak \\
\hline 13 & G13 & Gelisah / Susah Tidur \\
\hline 14 & G14 & Nyeri Didada \\
\hline 15 & G15 & Sering Muntah \\
\hline 16 & G16 & Nyeri Sekitar Wajah \\
\hline 18 & G17 & Nafas Berbau \\
\hline 19 & G18 & Sakit Pada Persendian Dan Otot \\
\hline 20 & G19 & Sakit Otot Dan Sendi \\
\hline
\end{tabular}

\section{Expert Rules.}

To reflect knowledge, a method in the form of IF-THEN is used. The rules used in this expert system are as follows:

\section{Rule 1}

IF Demam

AND batuk-batuk

AND hidung tersumbat/pilek

AND sakit kepala/pusing

AND sakit tenggorokan/susah telan

AND lesu/lemas

AND nyeri sekitar wajah

AND nafas berbau

AND perubahan warna ingus

THEN terdiagnosa penyakit rhinosinusitis

Table 1. Data Penyakit 
Rule 2

IF Demam

AND batuk-batuk

AND hidung tersumbat/pilek AND sakit kepala/pusing

AND sakit tenggorokan/susah telan

AND lesu/lemas

AND nafsu makan berkurang

AND nyeri sekitar wajah

AND nafas berbau

AND perubahan warna ingus

THEN terdiagnosa penyakit tonsilitis

Rule 3

IF Demam

AND batuk-batuk

AND hidung tersumbat/pilek

AND sakit kepala/pusing

AND sakit tenggorokan/susah telan

AND nafsu makan berkurang

AND nyeri sekitar wajah

AND nafas berbau

AND perubahan warna ingus

THEN terdiagnosa penyakit epiglottis

Rule 4

IF Demam

AND hidung tersumbat/pilek

AND sakit kepala/pusing

AND sakit tenggorokan/susah telan

AND sesak nafas/

AND frekuensi nafas cepat

AND nyeri sekitar wajah

AND nafas berbau

AND perubahan warna ingus

THEN terdiagnosa penyakit bronchitis

\section{Rule 5}

IF Demam

AND hidung tersumbat/pilek

AND sakit kepala/pusing

AND lesu/lemas

AND sesak nafas

AND frekuensi nafas cepat

AND suara nafas kasar

AND berkurangnya indra pengecap

AND sering muntah

THEN terdiagnosa penyakit bronkiolitis

Rule 6

IF Demam

AND batuk-batuk

AND sakit kepala/pusing

AND lesu/lemas

AND sesak nafas

AND frekuensi nafas cepat

AND suara nafas kasar

AND suara serak
THEN terdiagnosa penyakit pneumonia

Rule 7

IF Demam

AND batuk-batuk

AND sesak nafas

AND frekuensi nafas cepat

AND nafsu makan berkurang

AND nyeri dada

THEN terdiagnosa penyakit pleuritis

Rule 8

IF Demam

AND batuk-batuk

AND hidung tersumbat/pilek

AND sakit kepala/pusing

AND lesu/lemas

AND nafsu makan berkurang

AND berkurangnya indra pengecap

THEN terdiagnosa penyakit commond cold

Rule 9

IF Demam

AND batuk-batuk

AND sakit kepala/pusing

AND lesu/lemas

AND nafsu makan berkurang

AND sakit pada persendian

THEN terdiagnosa penyakit ILI

\section{Expert Decision Tree.}

After knowing the expert rules, then a decision tree can be made to assist in the process of making a rule base which will later be used to provide solutions to existing problem conditions. This decision tree is created using a depth-first search, which is an in-depth search of the rule from the root node moving downwards to successive deep levels. The decision tree for the expert application designed in this study is shown in Figure 2.

The search on the expert decision tree starts from the top node to the bottom node. The next process depends on how the answer will be given by the user. If the user gives symptoms, then the system will proceed to the next question, namely the second symptom, and so on until it finds the disease that occurs, and if the user does not give symptoms, the search will continue to another question node to determine the existing disease. Node G (Gejala) is associated with node $\mathrm{P}$ (Penyakit). For example P01, the rhinosinusitis is in sections G01-G20 and so on until P09. 


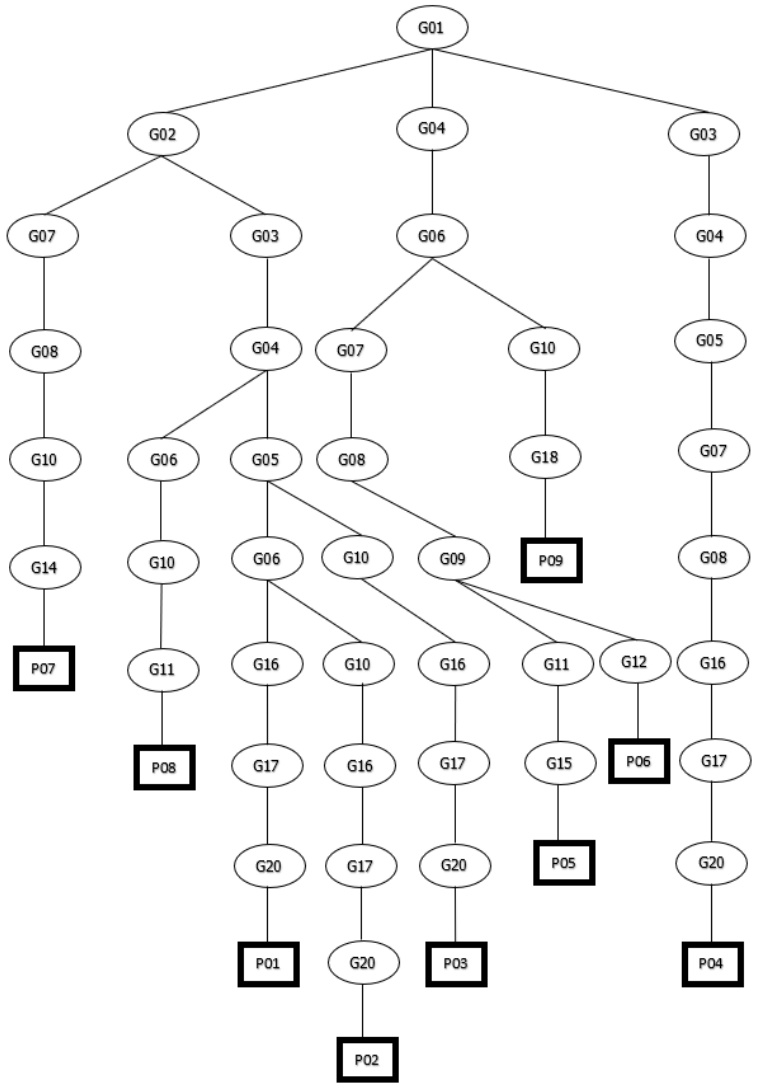

Figure 2. Decision Tree.

\section{Use Case Diagram Design.} its users.

The following is a design use case diagram of

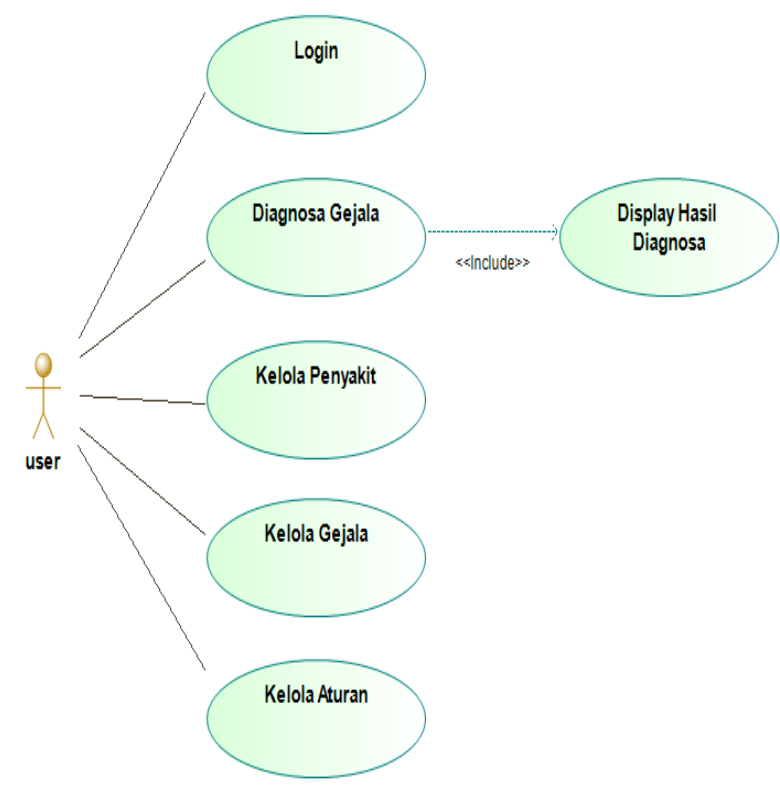

Figure 3. Use Case User.

Figure 3 describes the use case diagram of a user on an expert system for diagnosing acute respiratory infections. In the 'Login' use case, the actor performs is used to enter the system. For the use case data gejala is used to fill in data according to the complaints experienced by the user and the user uses the internet and a browser to use this website application. As for the kelola aturan use case, it is used to add and manage disease data and solutions that can be done and the user uses the internet and browser to use the website application. Use case Manage Symptoms is used to manage data on symptoms of disease and users use the internet and browsers to use website applications. Then for the use case kelola aturan is used to set the rules on the disease and the symptoms of the disease.

\section{Entity Relationship Diagram Design.}

In Figure 4 there are one/satu (1) and many/banyak (M) cardinality in the entity relationship diagram. Entities in the tbl_penyakit entity set are associated with more than one entity in the tbl_relasi entity set, and entities in the tbl_relasi entity set can only be associated with at most one entity in the tbl_penyakit entity set. the entity in the tbl_relasi set is associated with at most one entity in the tbl_gejala entity set and the entity in the tbl_gejala entity set is associated with more than one entity in the tbl_relasi entity set.

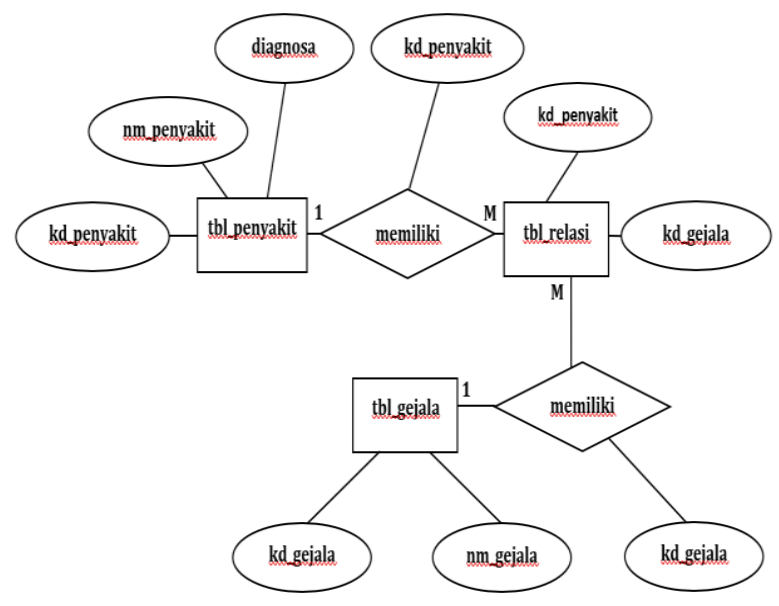

Figure 4. Entity Relationship Diagram

In addition, Figure 4 explains to model the data structure and the relationship between data, where there are three entities, namely tbl_penyakit, tbl_relasi, and tbl_gejala with the attributes in tbl_penyakit are kd_penyakit, nm_penyakit, and diagnosa. For attributes in tbl_relasi there are kd_penyakit, kd_gejala. As for the tbl_gejala attribute, it has kd_gejala and nm_gejala, which serve to make it easier to create relationships in databases and tables.

\section{User Interface Design.}


The user interface is used to provide an overview of the appearance of the application that will be used by the user.

a. Main Page Design User Login Menu.

In this menu there is a username and password column that must be filled in accordance with the time of registration on the system.

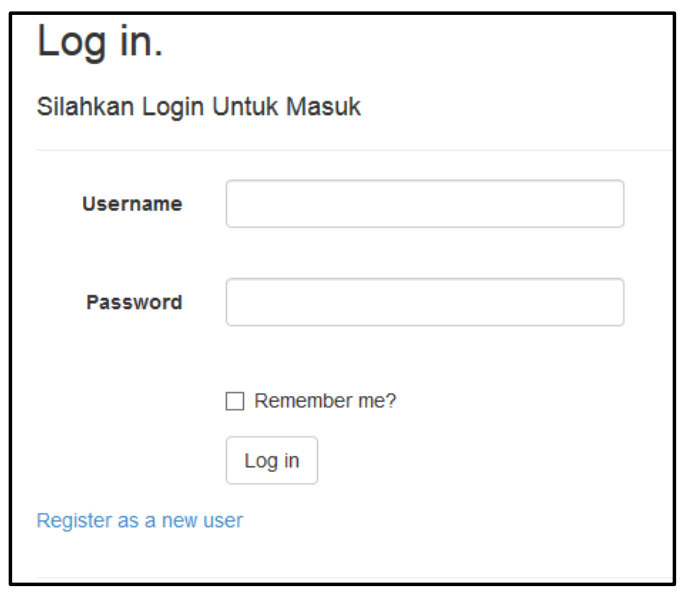

Figure 5. Form Login

Figure 5 describes the login form that serves to access the main page.

\section{b. Main Menu Page Design.}

After the user successfully logs in on the previous page, the home page will appear on the system and click the "Mulai Diagnosa" button to continue the system process.

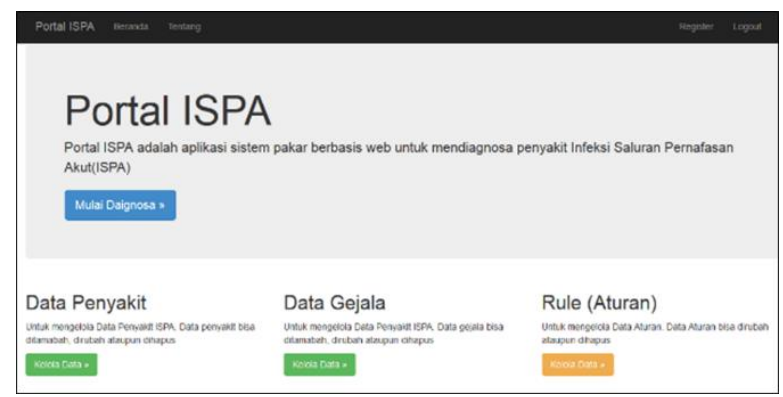

Figure 6. Halaman Utama

Figure 6 describes halaman utama portal used for the homepage and for continuing access to the data penyakit of page, data gejala of page, and the rules page.

c. Diagnostic Menu Page Design.

Figure 7 explains that the user will fill in the data, according to the complaints experienced by the user, in the form of a 'iya' or 'tidak' condition and there is a description that the symptoms experienced in 'G01', 'G02', 'G03'.

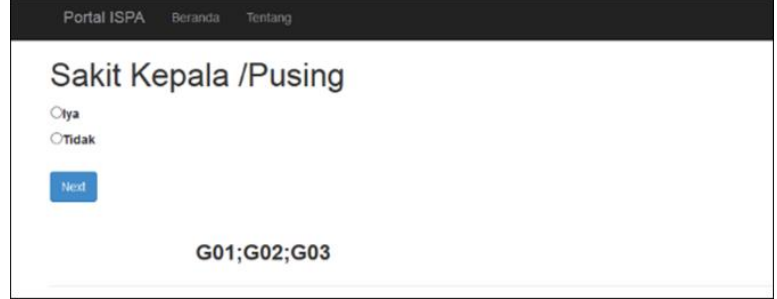

Figure 7. Diagnostic Menu

d. Results Menu Page Design.

After the diagnosis is made, a page will appear containing the results of the diagnosis and possible solutions.

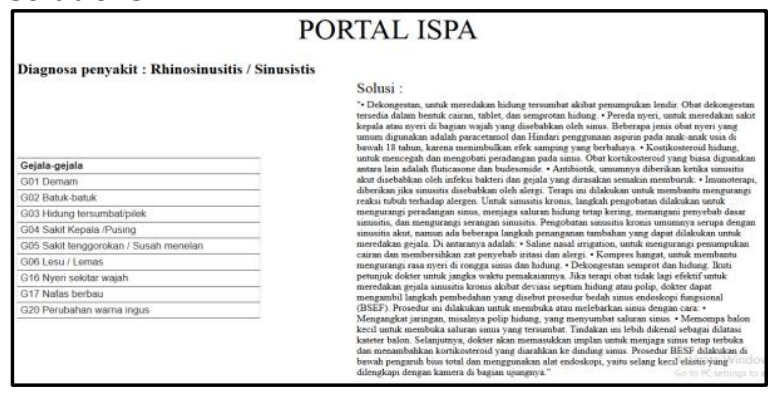

Figure 8. Results Menu

Figure 8 explains to find out the diagnosis of the disease based on the symptoms that have been summarized according to the options and solutions that can be given to the user.

e. Disease Data Manage Page Design.

This page is used to add and manage disease data and possible solutions.

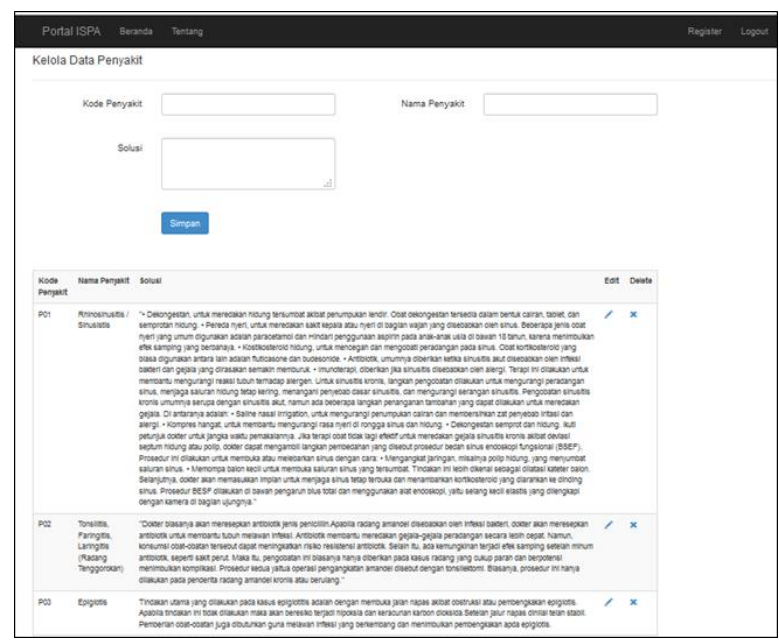

Figure 9. Data Penyakit Manage Page

In addition, Figure 9 explains that you can edit data penyakit and delete data penyakit.

f. Manage Data Gejala of Page Design.

On this page it is used to manage data gejala in disease. 


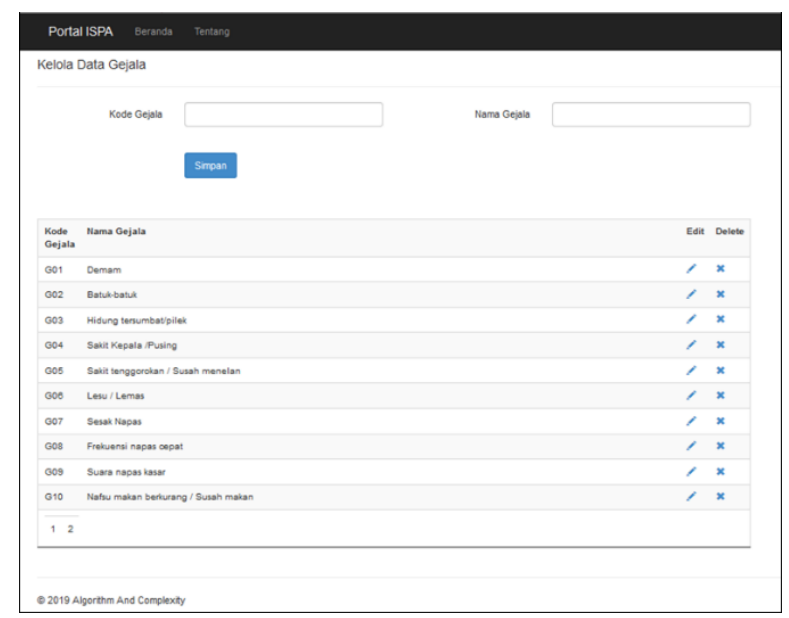

Figure 10. Manage Data Gejala Page.

Figure 10 functions to add, delete, or edit data gejala caused by the disease.

g. User Register Page Design.

This page is used to add users, so that they can access the system.

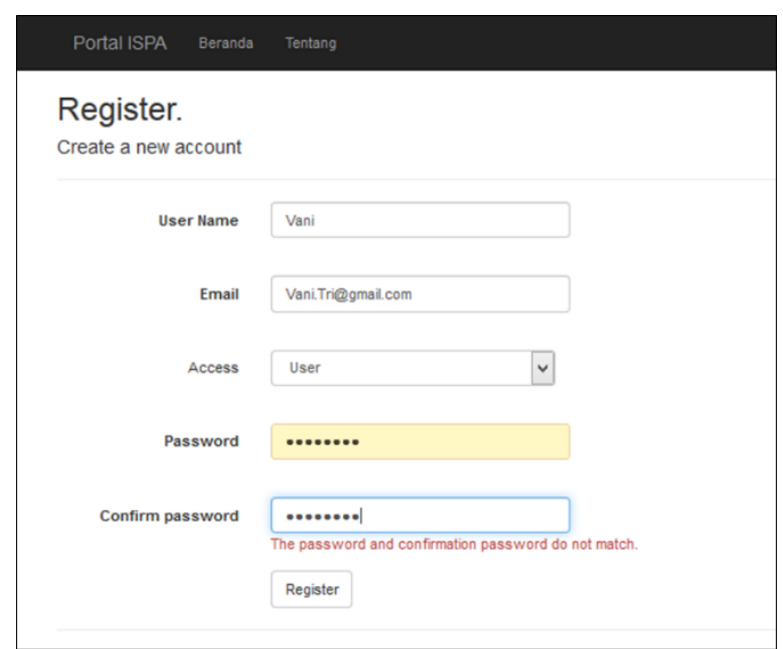

Figure 11. User Registration Page

While in Figure 11 it is explained to add a new user to access the system.

\section{CONCLUSION}

The expert system application created is based on a web base, so users can easily consult anytime anywhere just by accessing a browser. With this expert system, the general public can find out various kinds of symptoms and types of diseases and diagnoses given. For further development, it is hoped that more symptoms, types of diseases, and diagnoses will be added.

\section{REFERENCES}

Abdillah, A., Nurajijah, N., \& Nawawi, I. (2018). Perancangan Sistem Pakar Diagnosa Penyakit Kehamilan Berbasis Web. Jurnal Techno Nusa Mandiri, 15(2), 115. https://doi.org/10.33480/techno.v15i2.910

Afandi, H., \& Sulistyo, D. A. (2019). Sistem Pakar Untuk Diagnosa Hama dan Penyakit Pada Bunga Krisan Menggunakan Forward Chaining. Jurnal Ilmiah Teknologi Informasi Asia, 13(2), 101-114.

Fanny, R. R., Hasibuan, N. A., \& Buulolo, E. (2017). Perancangan Sistem Pakar Diagnosa Penyakit Asidosis Tubulus Renalis Menggunakan Metode Certainty Factor Dengan Penulusuran Forward Chaining. Media Informatika Budidarma, 1(1), 13-16.

Hidayat, H. A., \& Gumilang, G. (2017). Sistem Pakar Diagnosis Penyakit Yang Disebabkan Oleh Rokok Dengan Metode Forward Chaining. JUTEKIN, 5(2).

Jarti, N., \& Trisno, R. (2017). Sistem Pakar Diagnosa Penyakit Alergi Pada Anak Berbasis Web Dengan Metode Forward Chaining Di Kota Batam. Jurnal Edik Informatika, Penelitian Bidang Komputer Sains Dan Pendidikan Informatika, 2, 197-205.

Kusuma, D. T., Karmila, S., \& Nova, T. A. (2018). Forward Chaining Dalam Diagnosis Penyakit Tumbuhan Allium Cepa Var Aggregatum. Jurnal PETIR, 11(2), 164-178.

Maliki, O., \& Dangkua, F. (2018). Sistem Pakar Tipe Perumahan Menggunakan Metode Forward Chaining. Jurnal Informatika UPGRIS, 4(2), 150-157.

Mardiah, W., S. Mediawati, A., \& Setyorini, D. (2017). Pencegahan Penularan Infeksi pernapasan Akut dan Perawatannya Pada balita Di Rumah Di Kabupaten Panggandaran. Dharmakarya: Jurnal Aplikasi Ipteks Untuk Masyarakat ISSN $1410 \quad$ - 5675, 6(3), 258-261. http://jurnal.unpad.ac.id/dharmakarya/artic le/view/14853

Masya, F., Prastiawan, H., \& Mubaroq, S. (2016). Application Design to Diagnosis of Bone Fracture ( Traditional ) using Forward Chaining Methods. International Research Journal of Computer Science, 3(09), 23-30.

Minarni, D., Griha, I., \& Isa, T. (2017). Aplikasi Bagi Waris Islam dengan Metode Forward Chaining berbasis Web. Jurnal Online Informatika, 2(2), 127-133.

https://doi.org/10.15575/join.v2i2.107

Nuraeni, F., Agustin, Y. H., \& Yusup, E. N. (2016). Aplikasi Pakar Untuk Diagnosa Penyakit Kulit Menggunakan Metode Forward Chaining Di Al Arif Skin Care Kabupaten Ciamis. Seminar 
Nasional Teknologi Informasi Dan Multimedia 2016, 6-7.

Permata Sari, M., \& Realize. (2019). Sistem Pakar Mendiagnosa Penyakit Osteoporosis Pada Lansia Menggunakan Metode Forward Chaining Berbasis Web. Jurnal Ilmiah Informatika Universitas Putera Batam, 01.

Puspitawati, D. A. (2018). Sistem Pakar Diagnosis Penyakit Kanker Payudara Dan Cara Penanganannya. Jurnal Techno Nusa Mandiri, 15(2), https://doi.org/10.33480/techno.v15i2.921

Ramadhana, F., Fauziah, F., \& Winarsih, W. (2020). Aplikasi Sistem Pakar untuk Mendiagnosa Penyakit ISPA menggunakan Metode Naive Bayes Berbasis Website. STRING (Satuan Tulisan Riset Dan Inovasi Teknologi), 4(3), 320. https://doi.org/10.30998/string.v4i3.5441

Wahyudi, R., Utami, E., \& Arief, M. R. (2016). Sistem Pakar E-Tourism Pada Dinas Pariwisata D.I.Y Menggunakan Metode Forward Chaining. Jurnal Ilmiah DASI, 17(2).

Wulandari, A. D., \& Basuki, P. P. (2019). Hubungan Tingkat Pendidikan Formal Dan Pengetahuan Ibu Dengan Kejadian Infeksi Saluran Pernapasan Akut (ISPA) Pada Anak Usia 0-59 Bulan Di Kelurahan Bumijo Kecamatan Jetis Kota Yogyakarta. Journal of Chemical Information and Modeling, 8(2), 99-105. 